\title{
On the Economic Impact of International Sport Events: Microevidence from survey data at the EURO 2008.*
}

\author{
Michael J. Lamla ${ }^{\dagger}$ Martin Straub ${ }^{\ddagger}$ and Esther Mirjam Girsberger ${ }^{\S}$
}

July 2012

\begin{abstract}
Using firm-level data for up to 707 Swiss hotels and restaurants we evaluate the economic impact of the EURO 2008 soccer championship. Although aggregated macro data reveal no economic impact, we report an overall negative effect based on the surveyed companies. Notably the reported effects of the individual firms are very heterogeneous. For instance, hotels in cities benefitted from the tournament as they were able to raise prices and thereby increase profits. Looking at the long-run impact only a small fraction of companies do believe in a positive effect. Interestingly, this outlook does not depend on earnings, but on the guest structure.
\end{abstract}

JEL classification: L83, O18, R11

Keywords: Euro 2008, Mega-event, firm-level data.

\footnotetext{
*The views expressed in this paper are solely our own and not necessarily shared by the Swiss National Bank. We thank Thomas Bolli and Christoph Moser for helpful comments.

${ }^{\dagger}$ KOF Swiss Economic Institute, ETH Zurich, CH-8092 Zurich, Switzerland, E-mail: lamla @ kof.ethz.ch ${ }^{\ddagger}$ Swiss National Bank, Bundesplatz 1, P.O. Box, CH-3003 Bern, E-mail: martin.straub @ snb.ch.

${ }^{\S}$ Department of Economics, European University Institute, It-50133 Firenze, Italy, E-mail: esthermirjam.girsberger@eui.eu
} 


\section{Introduction}

Mega sport events receive a lot of attention not only by politicians but also by the general public. The desire for hosting such events is very high. The high investment costs required are usually justified by the gains in terms of reputation and positive short-run as well as long-run effects on the economy.

Although the common sense agrees with the presumed positive impact of major sport events, the academic literature investigating and quantifying the effects of hosting international sports tournaments or similar mega-events reports mixed evidence at best. For instance, Baade and Matheson (2004) argue that hosting World Cups does not always induce economically beneficial effects. In an ex-post analysis of the 1994 Word Cup held in the US the host cities experienced cumulative losses of 5.5-9.3 billion US-\$ instead of expected gains of 4 billion US-\$. Szymanski (2002) focuses on the impact of mega events on economic growth and estimates even a negative contemporary impact of a soccer World Cup. Similarly, Matheson (2006) and Matheson (2009) show that the economic impact of mega-events is mixed and question the magnitude of the economic multipliers researchers have calculated.

Obviously tracking the impact on economic growth does not tell you where the effect mainly stems from or if there are substitution effects present. Therefore, there are studies that explore effects on employment, tourism, trade and image. Studies from the German Bundesbank (Deutsche Bundesbank, 2006) as well as from the German Institute for Economic Research (DIW) (Brenke and Wagner, 2007) reveal positive but rather negligible effects of the soccer world championship. Concerning the quantification of the effect, theses studies focussed on expenditures of tourists and tourism in general. Other studies like Hagn and Maennig (2009) monitor the impact on the labor market and find no substantial reduction of unemployment rates in venue cities compared to other cities. Further evidence highlighting potential other effects like "feel-good" and public image is provided by Maennig and du Plessis (2007). Rose and Spiegel (2011) find significant and large trade effects for the hosting country. Remarkably, unsuccessful bids to host the Olympics have a similar impact on exports.

We contribute to this literature in two ways. First, we provide an empirical analysis based 
on firm-level data from a survey addressing restaurants and hotels. This is the sector which is supposedly most affected by the championship. On the basis of the survey, we infer whether the firms observed sales effects and whether these effects were greater or lower than expected. Thus, we can control for the counterfactual scenario as we extract how the sales growth would be without the EURO and can calculate the difference. The survey also investigates how the firms responded to the event in terms of price changes and in changes of capacity. This allows us to analyze the factors which affected changes in sales. Furthermore, we are able to track the role of capacity constraints. Second, we expand the scope by focussing on firms' long-term expectations. Long-term effects are often neglected in the literature. Welcome exceptions are works by Spilling (1996) and Jasmand and Maennig (2008). We analyze the link between short-run experiences and long-run expectations: on the basis of the survey, we investigate how the performance in terms of sales during the EURO 2008 affects the expectations of long-run economic impacts.

Overall, we find that no direct aggregate short-run impact of the EURO 2008 on the economy has been observable for Switzerland. The companies participating at the survey even reported, on average, that their realized sales were lower than the amount they would have expected without the Euro 2008. There is, however, a strong heterogeneity across firms. Using econometric means we provide evidence that especially hotels in city areas where games took place were better off. Contrary, restaurants in the same areas reported substantially worse sales effects. Finally, we show that only a small fraction of the surveyed companies believe in a positive long-run impact of the EURO 2008. Interestingly, that assessment does not depend on whether firms benefitted during the EURO 2008, but on wether they were visited by different or new customers.

The paper is structured as follows: In Section 2 we present aggregate data for Switzerland and test whether an EURO 2008 effect becomes apparent. Next, we introduce the survey and discuss the main results in Section 3. Finally, Section 4 concludes. 


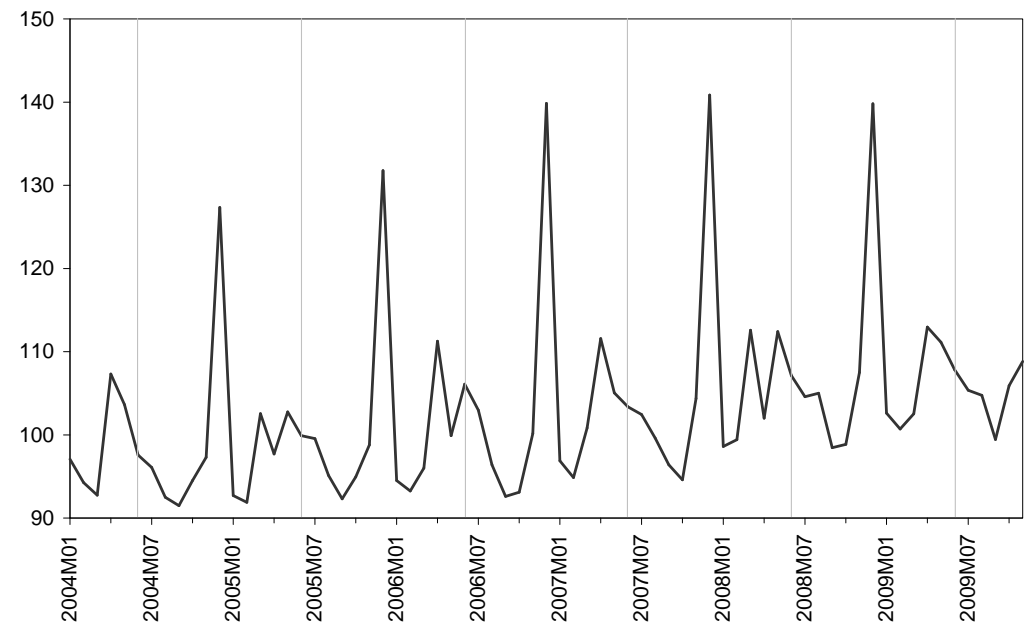

Figure 1: Retail sales in Switzerland: food, beverages and tobacco; at constant prices, adjusted for sales days. Index, 2005=100 (Source: Swiss Federal Statistical Office)

\section{Was there an Aggregate Effect of the EURO 2008?}

In the following we discuss the aggregate effects during the EURO 2008 (EURO hereafter) in Switzerland by analyzing retail sales and overnight stays. The EURO took place from June 7 to June 29, possible effects should thus be visible in the June readings. We start with the monthly retail sales figures. As the total retail sales contain many categories of goods which cannot be expected to be sold additionally because of the EURO (e.g., fuel or toilet articles), we examine the category "Food, Beverages and Tobacco". Although the latter is certainly not the only category to potentially benefit from the EURO, it is a category which can be expected to show a concentrated peak in June in the presence of EURO-related benefits.

Figure 1 shows the evolution of the Swiss retail sales since 2004, at constant prices and adjusted for sales days (June values are marked by vertical lines). Apart from the strong seasonal pattern, the figure shows that June 2008 was not an exceptionally strong month. The reading is better than the June 2007 reading, but this holds for the year 2008 in general. Furthermore, the values of the year 2009 are in the same range as the values of the year 2008 . 


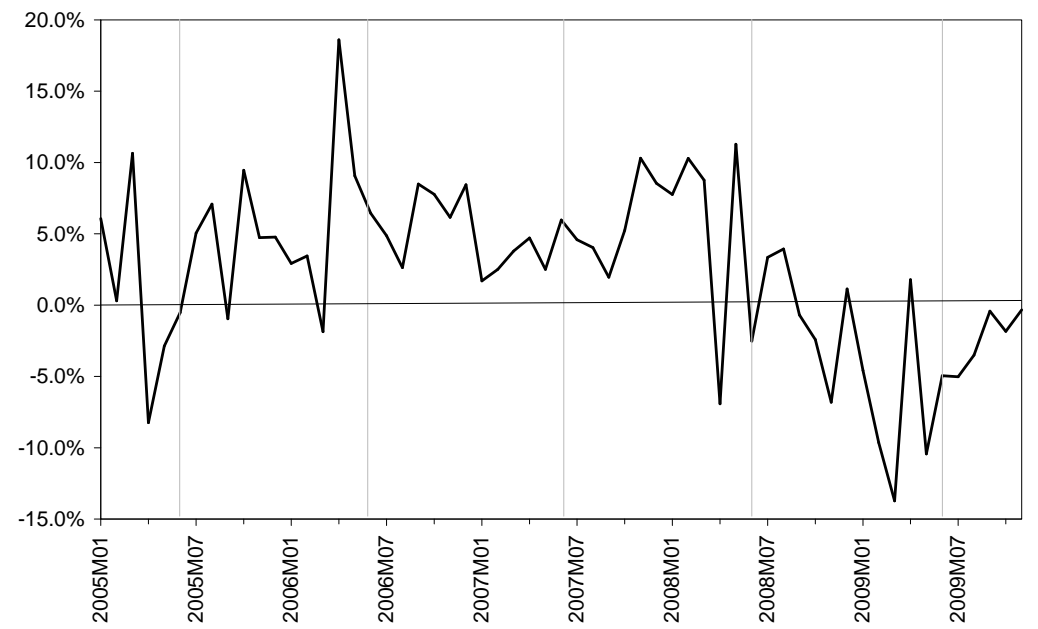

Figure 2: Overnight stays in Swiss hotels and health resorts, year-to-year growth rates (Source: Swiss Federal Statistical Office)

In the presence of strong EURO-induced benefits, we would expect the June 2009 reading to lie below the June 2008 reading. We thus conclude that there is no clear EURO effect visible in the retail sales of food, beverages and tobacco.

We now turn to overnight stays in hotels and health resorts in order to assess the effect of the EURO on the Swiss hotel sector. Figure 2 shows the year-on-year growth rates of the number of overnight stays in hotels and health resorts in Switzerland. Interestingly, the growth rate was negative in June 2008, i.e. less overnight stays were registered than in June 2007. The EURO thus seems to have brought rather disappointing effects for the hotel sector. The Swiss Hotel Association explains this result by the fact that many congresses and seminars that would usually have been held in June were rescheduled or canceled because of the EURO ${ }^{1}$. The EURO thus caused a crowding out effect in the hotel sector which was not entirely compensated by the presence of football fans.

\footnotetext{
${ }^{1}$ Cp. press release of the Swiss Hotel Association from 2008/08/08
} 


\section{Evidence from Microdata}

As the aggregate data may wash out the effects of the EURO we rest our main analysis on a firm level analysis. In the first part we will introduce the data and discuss the descriptive evidence which highlights remarkable differences in the experience regarding the EURO. In the second part we will test the possible determinants of a potential positive or negative effect using econometric means.

\subsection{The Survey}

In order to assess the effects of the EURO more in detail, a questionnaire was sent out to 1285 hotels and restaurants, of which 707 answered. The response rate thus amounted to $55 \%$. Table 8 shows the questions asked together with the variable names and encodings used in the analysis. The core of the questionnaire were the estimated immediate effects and the expected long run effects of the EURO. The participants were asked twice about the effect they estimated the EURO to have on their sales. The first question was categorical and asked whether the expected sales effect was positive, zero or negative. Additionally, the firms were interrogated if this effect had turned out as expected or worse/better than expected. In order to estimate the immediate effects quantitatively, the firms were furthermore asked for the evolution of their sales in June 2008 as compared to June 2007, as well as for the respective evolution they would have expected without the EURO taking place. We define the short run EURO premium as the difference between the effective sales growth and the hypothetical growth expected without the EURO. This sales premium variable therefore already controls for a counterfactual scenario of sales in the absence of the soccer tournament. Thus, we do not need a difference-in-difference methodology to identify the EURO 2008 effects. With regard to the long-run effects, the firms were directly asked if they expect any such effects for themselves. Further questions about the business development in June 2008 concerned the amount of food and drinks sold for restaurants, respectively the amount of overnight stays for hotels, the type of guests received and for hotels additionally the average length of stay of the guests. Finally, the questionnaire inquired whether the firms increased their capacities or 
charged different prices during the EURO. As additional explanatory variables, we include the number of employees and dummies for the tourism zones and the hotel sector in our analysis.

With respect to the categorical question, only $25 \%$ of the corresponding answers indicated positive sales effects during the EURO. On the other hand, $28 \%$ indicated negative sales effects. With regard to the element of surprise, $11 \%$ of the answers indicated that the effect had turned out better than they had expected. The corresponding share of negative surprises amounted to $29 \%$. Additional details are shown in Table 1.

Table 1: Contingency Table for categorical question on sales effects and realization of expectations (absolute numbers in parantheses)

\begin{tabular}{lccc|c}
\hline & $\begin{array}{c}\text { Sales effect } \\
\text { negative }\end{array}$ & $\begin{array}{c}\text { No effect } \\
\text { on sales }\end{array}$ & $\begin{array}{c}\text { Sales effect } \\
\text { positive }\end{array}$ & Total \\
\hline Worse than expected & $16 \%(111)$ & $6 \%(44)$ & $7 \%(45)$ & $29 \%(200)$ \\
As expected & $10 \%(69)$ & $36 \%(248)$ & $13 \%(85)$ & $59 \%(402)$ \\
Better than expected & $2 \%(12)$ & $4 \%(27)$ & $6 \%(39)$ & $11 \%(78)$ \\
\hline Total & $28 \%(192)$ & $47 \%(319)$ & $25 \%(169)$ & $100 \%(680)$ \\
\hline
\end{tabular}

The slightly negative assessment of the sales effect is also visible in the quantitative sales differences which the participants stated. Figure 3 shows the mean values for the short run EURO premium for all participants, as well as for the two sectors and the three firm size categories. Figure 4 shows the corresponding box plots. The mean EURO premium over the whole sample lies at -2.8 percentage points, i.e. the participants estimated on average that their sales growth was diminished by 2.8 percentage points by the EURO. However, the figures reveal considerable differences between the sectors, regions and firm size categories. With regard to the sector, we note that restaurants rated the EURO effect on average clearly negative (-4.8 percentage points), while hotels estimated it on average only slightly negative (-0.2 percentage points). All four tourism zones ("Mountains", "Lakes", "Big Cities", "Other areas") report clearly negative effects on average. The Boxplots reveal that the zone "Big Cities" has the largest share of positive reported premiums, but also the largest dispersion. The division into firm size categories ${ }^{2}$ shows clearly negative results on average for small and medium firms. The big firms reported less pessimistic results, but also showed the largest

\footnotetext{
${ }^{2}$ Small firms: up to 9 employees; medium firms: 10 to 49 employees; big firms: 50 employees and more
} 


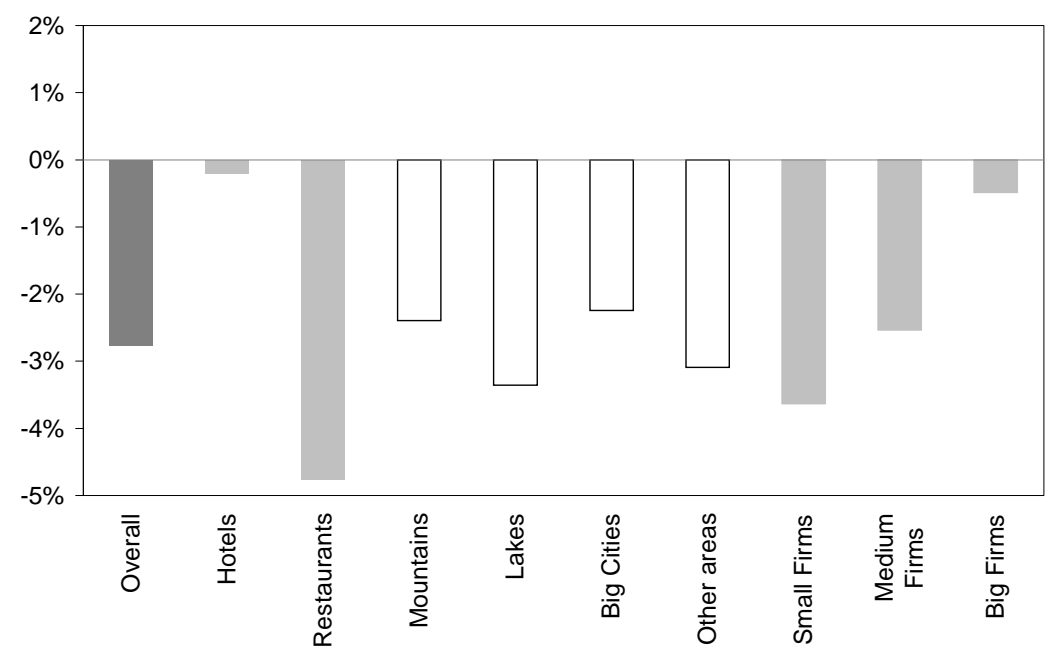

Figure 3: Short run EURO premium, mean values for whole sample, sectors, regions and firm size categories in percentage points

dispersion. As the dispersion is rather high in general, neither the mean over all participants nor the mean over any of the mentioned subcategories is significantly different from zero. Actually, the share of firms estimating a zero direct effect is not to be underestimated: the median lies at zero for all categories, and $36 \%$ of the answers estimated the effect to be zero. The shares of positive and negative estimated premia lie at $23 \%$ and $40 \%$, respectively.

Prices were increased predominantly in hotels during the EURO. From those firms having increased their prices, $55 \%$ estimated a positive premium. As this share exceeds the share of overall positive answers (23\%), raising prices seems having paid off in most cases.

An interesting question arises with respect to the expectations regarding a long-run effect of the EURO 2008. Although only those participants which had estimated a positive sales premium were invited to answer this question, table 2 shows that it was answered actively by participants having estimated negative, zero and positive premia. The question concerning the expected long run effects was answered by $53 \%$ of all participants. Out of these answers, a vast majority of $77 \%$ ( $41 \%$ of the total number of participants) stated that they did not expect to profit from the EURO in the long run. Out of those firms expecting long run benefits, $84 \%$ 


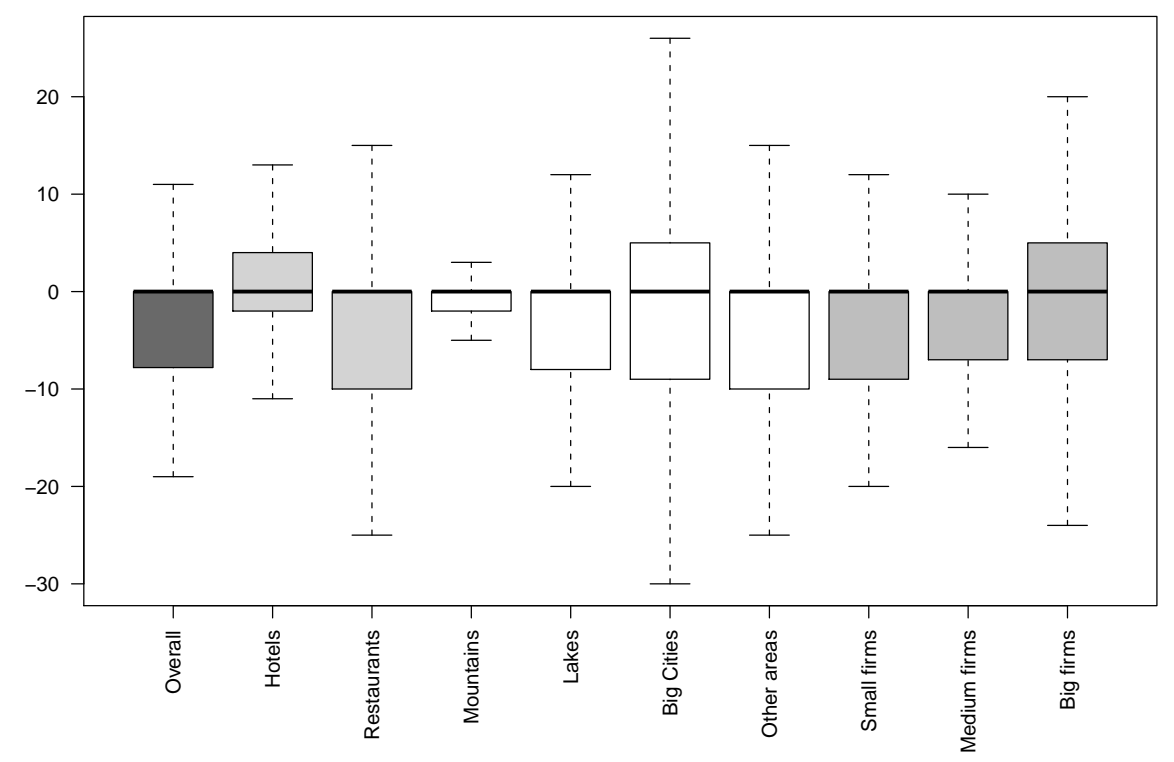

Figure 4: Short run EURO premium, box plots for whole sample, sectors, regions and firm size categories in percentage points

indicated the they anticipated gaining additional customers, while $32 \%$ counted on image gains for Switzerland (multiple entries were possible). The share of participants expecting no long run effects exceeds the one of participants expecting long effects for all categories of estimated sales premia (in total $41 \%$ vs. 12\%). Furthermore, this table allows us to test whether these expectations regarding the long run effects are conditional on the short-run experience during the EURO championship. Very interestingly, our results show that the answers seem to be idiosyncratic and that we do not see a systematic connection between the estimated sales premium and the corresponding expected long run effect. From those firms that expect a positive long-run effect, $5 \%$ estimated positive sales premia, but there were also $4 \%$ which had suffered a negative premium and despite that expected positive effects in the future. A similar picture emerges for the group of companies that expected no long-run effect: while $10 \%$ experienced a negative sales premium, $8 \%$ had a positive sales premium. 
Table 2: Contingency Table for short run / long run effects (absolute numbers in parentheses)

\begin{tabular}{lccc|c}
\hline & $\begin{array}{c}\text { No long run effect } \\
\text { expected }\end{array}$ & $\begin{array}{c}\text { Long run effect } \\
\text { expected }\end{array}$ & $\begin{array}{c}\text { No answer } \\
\text { long run effect }\end{array}$ & Total \\
\hline Sales premium $<0$ & $10 \%(70)$ & $4 \%(25)$ & $17 \%(119)$ & $31 \%(214)$ \\
Sales premium $=0$ & $13 \%(93)$ & $2 \%(14)$ & $12 \%(85)$ & $27 \%(192)$ \\
Sales premium $>0$ & $8 \%(59)$ & $5 \%(36)$ & $4 \%(29)$ & $18 \%(124)$ \\
$\begin{array}{l}\text { No answer concerning } \\
\text { Sales premium }\end{array}$ & $9 \%(64)$ & $2 \%(11)$ & $14 \%(96)$ & $24 \%(171)$ \\
\hline Total & $41 \%(286)$ & $12 \%(86)$ & $47 \%(329)$ & $100 \%(701)$ \\
\hline
\end{tabular}

\subsection{Econometric Analysis}

Our descriptive analysis has shown that the impact of the EURO championship was on average negative but also revealed substantial variation across the individual companies surveyed. In the following section, we try to identify the variables driving EURO premium empirically. We would like to highlight to which extent the outcome is driven by strategic changes in prices, quantities and capacities. Furthermore, we will also concentrate on the determinants of the long-term assessment and test whether current experiences are linked to the long-run assessment. For instance, one could easily conjecture that individual restaurants or hotels that reported positive premia at the soccer tournament are also more likely to expect long-run gains.

\subsubsection{Immediate Sales Premium impact}

To analyze the short-run impact on the sales premium as defined in Table 8 we estimate the following equation:

$$
s_{i}=\alpha+\beta_{1} p_{i}+\beta_{2} q_{i}+\Gamma^{\prime} X_{i}+\varepsilon_{i}
$$

where $s$ is the return premium, $p$ denotes the price component, $q$ the quantity component, $X$ is a vector containing further control variables (company characteristics), $\beta_{i}$ 's and $\Gamma$ are coefficient estimates and $\varepsilon_{i}$ is an i.i.d error term. We use ordinary least squares estimation with robust standard errors. As the sales premium has a price and a quantity component, we control for both in order to test whether different premia are driven by changes in prices 
or quantity. Furthermore, we include company specific attributes like location, type and employees. Finally, we control for capacity expansions and changes in the guest structure.

We start with the overall sample. The results in Table 3 show that the quantity component plays an important role as it is statistically significant at the 1\%-level. On the other hand, the price component is not significantly related to the Euro premium at this stage. Thus, the sales premium was driven by quantity effects. Furthermore, companies which had expanded their capacities reported higher premia. This makes sense as they could serve more customers and thus increase their profits. Finally, hotels in big cities experienced higher premia. This is in line with our expectations as basically all major cities in Switzerland served as a venue. Hotels in big cities thus seem to have profited from the presence of fans. Apart from the hotels in big cities, neither location nor firm size is relevant for reaping the benefits of the championship.

In a next step we split our sample into restaurants and hotels and estimate columns (1) and (2) of Table 3 separately. The results are presented in Tables 4 and 5. From the results it becomes apparent that hotels and restaurants have been affected differently. Starting from the top, in both cases profit effects were driven by quantity effects during the EURO 2008. With regard to the price components, we note that only hotels have a positive impact from the price on the sales. About $30 \%$ of the participating hotels increased their prices, which increased their sales on average. On the other hand, only very few restaurants changed their prices. It seems plausible that hotels are more likely to adjust their prices for overnight stays. Restaurants on the other hand faced increased competition during the soccer championship due to the established 'fan-zones'.

Concerning the location, the results differ in the cities: while restaurants in big cities recorded negative sales premia, hotels in big cities increased their sales, i.e. had more guests. Furthermore, expanded capacities influenced sales only for restaurants. In addition, the guest structure had an impact on the sales premium for hotels: those hotels receiving other guests than usual reported higher premia. Interestingly, the size of the restaurant or hotel did not matter in any case. 
Table 3: Regression results for short run EURO premium, hotels and restaurants

\begin{tabular}{|c|c|c|}
\hline VARIABLES & $\begin{array}{c}(1) \\
\text { sales_diff }\end{array}$ & $\begin{array}{c}(2) \\
\text { sales_diff }\end{array}$ \\
\hline quantity & $\begin{array}{c}6.57^{* * *} \\
(0.69)\end{array}$ & $\begin{array}{c}6.54^{* * *} \\
(0.66)\end{array}$ \\
\hline prices & $\begin{array}{l}1.99 \\
(1.34)\end{array}$ & \\
\hline hotel & $\begin{array}{l}-0.49 \\
(1.15)\end{array}$ & \\
\hline log_empl & $\begin{array}{l}-0.04 \\
(0.60)\end{array}$ & \\
\hline mountain & $\begin{array}{l}-1.41 \\
(1.36)\end{array}$ & \\
\hline lake & $\begin{array}{l}0.27 \\
(1.49)\end{array}$ & \\
\hline city & $\begin{array}{l}-3.05 \\
(1.93)\end{array}$ & \\
\hline guest_struc & $\begin{array}{c}3.40^{* *} \\
(1.38)\end{array}$ & $\begin{array}{c}3.65^{* * *} \\
(1.31)\end{array}$ \\
\hline capacity_temp & $\begin{array}{l}3.87^{*} \\
(2.11)\end{array}$ & $\begin{array}{l}3.63^{*} \\
(2.16)\end{array}$ \\
\hline hot_city & $\begin{array}{c}6.37^{* *} \\
(2.64)\end{array}$ & $\begin{array}{c}4.85^{* * *} \\
(1.85)\end{array}$ \\
\hline Constant & $\begin{array}{c}-3.09^{* *} \\
(1.43)\end{array}$ & $\begin{array}{c}-4.14^{* * *} \\
(0.54)\end{array}$ \\
\hline $\begin{array}{l}\text { Observations } \\
R^{2}\end{array}$ & $\begin{array}{c}464 \\
0.298\end{array}$ & $\begin{array}{c}465 \\
0.285\end{array}$ \\
\hline
\end{tabular}


Table 4: Regression results for short run EURO premium, restaurants only

\begin{tabular}{|c|c|c|}
\hline VARIABLES & $\begin{array}{c}(1) \\
\text { sales_diff }\end{array}$ & $\begin{array}{c}(2) \\
\text { sales_diff }\end{array}$ \\
\hline quantity & $\begin{array}{c}7.89^{* * *} \\
(1.05)\end{array}$ & $\begin{array}{c}8.02^{* * *} \\
(0.91)\end{array}$ \\
\hline prices & $\begin{array}{l}-2.15 \\
(2.46)\end{array}$ & \\
\hline log_empl & $\begin{array}{l}-0.44 \\
(0.98)\end{array}$ & \\
\hline mountain & $\begin{array}{l}-1.28 \\
(1.81)\end{array}$ & \\
\hline lake & $\begin{array}{l}-0.91 \\
(1.82)\end{array}$ & \\
\hline city & $\begin{array}{l}-3.09 \\
(2.00)\end{array}$ & \\
\hline guest_struc & $\begin{array}{l}2.18 \\
(2.24)\end{array}$ & \\
\hline capacity_temp & $\begin{array}{c}5.91^{* *} \\
(2.54)\end{array}$ & $\begin{array}{c}5.55^{* *} \\
(2.37)\end{array}$ \\
\hline Constant & $\begin{array}{l}-1.82 \\
(1.86)\end{array}$ & $\begin{array}{c}-3.77^{* * *} \\
(0.62)\end{array}$ \\
\hline $\begin{array}{l}\text { Observations } \\
R^{2}\end{array}$ & $\begin{array}{c}262 \\
0.303\end{array}$ & $\begin{array}{c}263 \\
0.285\end{array}$ \\
\hline
\end{tabular}


Table 5: Regression results for short run EURO premium, hotels only (1) (2) VARIABLES sales_diff sales_diff

\begin{tabular}{|c|c|c|}
\hline quantity & $\begin{array}{c}5.19^{* * *} \\
(0.87)\end{array}$ & $\begin{array}{c}5.13^{* * *} \\
(0.84)\end{array}$ \\
\hline prices & $\begin{array}{l}2.84^{*} \\
(1.63)\end{array}$ & $\begin{array}{c}3.75^{* * *} \\
(1.39)\end{array}$ \\
\hline log_empl & $\begin{array}{c}0.16 \\
(0.69)\end{array}$ & \\
\hline mountain & $\begin{array}{l}-0.22 \\
(2.76)\end{array}$ & \\
\hline lake & $\begin{array}{c}2.53 \\
(2.92)\end{array}$ & \\
\hline city & $\begin{array}{c}3.88 \\
(3.56)\end{array}$ & \\
\hline guest_struc & $\begin{array}{c}4.70^{* * *} \\
(1.72)\end{array}$ & $\begin{array}{c}5.11^{* * *} \\
(1.44)\end{array}$ \\
\hline capacity_temp & $\begin{array}{l}-2.52 \\
(3.68)\end{array}$ & \\
\hline guest_length & $\begin{array}{c}2.89 \\
(1.87)\end{array}$ & \\
\hline Constant & $\begin{array}{l}-5.61 \\
(3.59)\end{array}$ & $\begin{array}{c}-3.97^{* * *} \\
(0.81)\end{array}$ \\
\hline $\begin{array}{l}\text { Observations } \\
R^{2}\end{array}$ & $\begin{array}{c}187 \\
0.328\end{array}$ & $\begin{array}{c}209 \\
0.279\end{array}$ \\
\hline
\end{tabular}

Robust standard errors in parentheses ${ }^{* * *} \mathrm{p}<0.01,{ }^{* *} \mathrm{p}<0.05,{ }^{*} \mathrm{p}<0.1$ 


\subsubsection{Long-run impact}

Most studies on the economic impact of sports events focus on short-run effect only. In our survey, we also asked firms whether they expected any long-run impact of the EURO. In this section, we investigate the determinants of the probability to believe in a positive longrun impact of the EURO. The obvious main candidate is the short-run experience from the championship. This experience can be driven by monetary issues like the sales premium. But also surprises may be important, like unexpected additional guests or an unexpectedly high sales premium. We thus control for the surprise component in the EURO premium and conjecture an unexpected sales premium to affect the long-run assessment.

We employ a probit model of the standard form:

$$
P(Y=1 \mid x)=\Phi\left(x^{\prime} \beta\right)
$$

where $P$ is the probability, $\Phi$ is the Cumulative Distribution Function (CDF) of the standard normal distribution. The parameters $\beta$ are estimated by maximum likelihood.

We control for the sales premium of the firms and therefore for the pecuniary effect, for the social effect as represented by changes in the guest structure and for the surprise component.

Our results are as follows. Table 6 column (1) shows the basic estimation using an ordered variable (values $-1,0,1$ ) for the EURO sales premium and controlling for firm size, tourism zone, type (hotel or restaurant), the guest structure and expanded capacities. Surprisingly but not fully unexpectedly given Table 2, we find no relationship between sales premium and the expectations regarding the long-run impact. This implies that companies answered independently of having benefitted or suffered from the EURO in terms of sales. Furthermore, while we find no impact of size or location of the company on the response pattern, the guest structure, expanded capacities and a hotel dummy are of great importance. Accordingly, hotels on the one hand and firms having expanded their capacities temporarily and/or having received other guests than usual during the EURO on the other hand expect positive longrun effects with a higher probability. In column (2) we include only the variables that were statistically significant in column (1). Going from a general to a more specific setup does 
not alter the results. Thus, we can conclude that the assessment of future prospects is more influenced by social interaction than by monetary benefits. Those firms which received other guests than usual during the EURO are more optimistic. The same holds for firms having expanded their capacities temporarily. The final column (3) shows that the surprise component is of great importance. Both positive and negative surprise exert a meaningful impact on the probability of responding positively to this question. Furthermore, it seems that positive surprises outperform negative surprises. We can deduct from this result that unexpected occurrences matter for the long-run assessment. While in most studies, especially in finance, negative surprise dominate, like for instance in stock market, in this case positive surprise tend to dominate negative surprises in terms of the size of the coefficient.

\subsubsection{Robustness}

In order to check the robustness of our results, we estimate the same model as in section 3.2.1 using categorical variables. While including a continuous figure for the sales premium allowed us to quantify the effects, the numbers indicated by the firms might be subject to random individual errors. The resulting estimator would then still be consistent and unbiased, but the confidence bands would widen. To account for that, we transform the sales premia into a new categorical variable capturing the sign of the sales premia (thus the categories are: $-1,0,1)$. This setup requires us to switch to a different estimation technique, namely ordered probit estimation. Probit estimations are a special case of ordered probit. Instead of two outcomes, we are now dealing with three outcomes. Thus, the equation amends to:

$$
\begin{aligned}
P(Y=1 \mid X) & =1-\Phi\left(x^{\prime} \beta\right) \\
P(Y=0 \mid X) & =\Phi\left(\mu-x^{\prime} \beta\right)-\Phi\left(x^{\prime} \beta\right) \\
P(Y=-1 \mid X) & =1-\Phi\left(\mu-x^{\prime} \beta\right),
\end{aligned}
$$

where in addition to the previous estimation procedure $\mu$ is the cutoff point. Above from these adjustments we employ the same set of explanatory variables.

The results are presented in Table 7 . The first two columns show the same regressions as 
Table 6: Regression results for long run effects

\begin{tabular}{|c|c|c|c|}
\hline & $\begin{array}{c}(1) \\
\text { long_run_eff }\end{array}$ & $\begin{array}{c}(2) \\
\text { long_run_eff }\end{array}$ & $\begin{array}{c}(3) \\
\text { long_run_eff }\end{array}$ \\
\hline sales_diff_ordered & $\begin{array}{l}-0.03 \\
(0.11)\end{array}$ & & \\
\hline size & $\begin{array}{c}0.07 \\
(0.13)\end{array}$ & & \\
\hline mountain & $\begin{array}{l}0.15 \\
(0.29)\end{array}$ & & \\
\hline lake & $\begin{array}{l}0.10 \\
(0.28)\end{array}$ & & \\
\hline city & $\begin{array}{l}-0.15 \\
(0.32)\end{array}$ & & \\
\hline hotel & $\begin{array}{c}0.37 \\
(0.24)\end{array}$ & $\begin{array}{c}0.53^{* * *} \\
(0.17)\end{array}$ & \\
\hline guest_struc & $\begin{array}{c}1.02^{* * * *} \\
(0.22)\end{array}$ & $\begin{array}{c}0.99^{* * *} \\
(0.18)\end{array}$ & \\
\hline capacity_temp & $\begin{array}{c}0.68^{* * *} \\
(0.24)\end{array}$ & $\begin{array}{c}0.62^{* * *} \\
(0.22)\end{array}$ & \\
\hline hot_city & $\begin{array}{c}0.29 \\
(0.39)\end{array}$ & & \\
\hline surprise_positive & & & $\begin{array}{c}0.85 * * * \\
(0.24)\end{array}$ \\
\hline surprise_negative & & & $\begin{array}{c}-0.57^{* *} \\
(0.28)\end{array}$ \\
\hline Constant & $\begin{array}{c}-1.61^{* * *} \\
(0.31)\end{array}$ & $\begin{array}{c}-1.53^{* * *} \\
(0.14)\end{array}$ & $\begin{array}{c}-0.76^{* * *} \\
(0.08)\end{array}$ \\
\hline Observations & 282 & 346 & 370 \\
\hline Pseudo $R^{2}$ & 0.20 & 0.20 & 0.05 \\
\hline
\end{tabular}

Standard errors in parentheses

${ }^{* * *} \mathrm{p}<0.01,{ }^{* *} \mathrm{p}<0.05,{ }^{*} \mathrm{p}<0.1$ 
Table 7: Robustness Check for short run EURO premium, hotels and restaurants

\begin{tabular}{|c|c|c|c|}
\hline VARIABLES & $\begin{array}{c}(1) \\
\text { sales_diff_ordered }\end{array}$ & $\begin{array}{c}(2) \\
\text { sales_diff_ordered }\end{array}$ & $\begin{array}{c}(3) \\
\text { sales_diff_ordered }\end{array}$ \\
\hline quantity & $\begin{array}{c}0.74^{* * *} \\
(0.07)\end{array}$ & $\begin{array}{c}0.74^{* * *} \\
(0.07)\end{array}$ & $\begin{array}{c}0.75^{* * *} \\
(0.07)\end{array}$ \\
\hline prices & $\begin{array}{l}0.28^{*} \\
(0.16)\end{array}$ & & $\begin{array}{c}0.36^{* *} \\
(0.15)\end{array}$ \\
\hline hotel & $\begin{array}{c}0.1 \\
(0.14)\end{array}$ & & \\
\hline size & $\begin{array}{l}-0.14 \\
(0.09)\end{array}$ & & \\
\hline mountain & $\begin{array}{l}-0.01 \\
(0.16)\end{array}$ & & \\
\hline lake & $\begin{array}{l}0.19 \\
(0.16)\end{array}$ & & \\
\hline city & $\begin{array}{c}0 \\
(0.18)\end{array}$ & & \\
\hline guest_struc & $\begin{array}{c}0.36^{* *} \\
(0.15)\end{array}$ & $\begin{array}{c}0.40^{* * *} \\
(0.14)\end{array}$ & $\begin{array}{c}0.31^{* *} \\
(0.14)\end{array}$ \\
\hline capacity_temp & $\begin{array}{c}-0.1 \\
(0.18)\end{array}$ & $\begin{array}{l}-0.15 \\
(0.17)\end{array}$ & \\
\hline hot_city & $\begin{array}{l}0.47^{*} \\
(0.28)\end{array}$ & $\begin{array}{c}0.55^{* * *} \\
(0.2)\end{array}$ & $\begin{array}{l}0.41^{*} \\
(0.22)\end{array}$ \\
\hline $\begin{array}{l}\text { Observations } \\
\text { Pseudo } R^{2} \\
\text { cut1 }\end{array}$ & $\begin{array}{c}464 \\
0.18 \\
-0.34^{*} \\
(0.18)\end{array}$ & $\begin{array}{c}465 \\
0.17 \\
-0.22^{* * *} \\
(0.07)\end{array}$ & $\begin{array}{c}485 \\
0.18 \\
-0.19^{* * *} \\
(0.07)\end{array}$ \\
\hline cut2 & $\begin{array}{c}0.90^{* * *} \\
(0.18)\end{array}$ & $\begin{array}{c}1.01^{* * *} \\
(0.08)\end{array}$ & $\begin{array}{c}1.05^{* * *} \\
(0.08)\end{array}$ \\
\hline
\end{tabular}

*** $\mathrm{p}<0.01,{ }^{* *} \mathrm{p}<0.05,{ }^{*} \mathrm{p}<0.1$

Standard errors in parentheses

Encoding of variable size: 1: 1 to 9 employees; 2: 10 to 49 employees; 3: more than 49 employees. 
Table 3, column (3) shows the results obtained by using significant variables only. Overall - now judging only on the direction of the link and its significance - we can confirm the result retrieved from the estimations in Section 3.2.1 for the gross of our variables. That said, there are some differences. First, the variable capturing price changes is now significant. Thus the price adjustment stemming from hotels seems to materialize more strongly in the full sample regression. Furthermore, the variable capturing capacity expansions loses its statistical significance. Thus, we must differentiate our results to the degree that in a qualitative analysis, there is also a price effect in addition to the already known quantity effect. On the other hand, we can reinforce the result that hotels in cities were better off in terms of the sales premium.

Finally, we check whether there may be any kind of selection bias present in our study. As we have received surveys where the critical sales question has not been answered we need to control whether leaving out theses firms affects our estimation. For this purpose we conduct a Heckman selection estimation. Results are presented in Table 9. As can be seen from the table, the selection issue seems to be of minor importance as the explanatory power of the first stage regression is very low. The partial pseudo R-Squared of the significant explanatory variables at this stage is roughly $0.02 \%$. Furthermore, the second stage results are therefore very similar to the results obtained without this correction for a potential selection bias.

\section{Conclusions}

It is commonly believed that major sport event have a huge and positive economic impact. Several recent studies already investigated a possible economic effect of such major sport events and find rather disappointing results regarding the potential benefits. The empirical evidence reveals either rather small positive effects or very mixed results. In this study, we add to the existing literature by providing evidence on the impact of the EURO 08 championship based on firm-level survey data. While the overall effect may vanish rapidly or be averaged out, micro-level evidence allows us to track the effects more directly. In addition, we can control for a counterfactual and we are able to search the determinants of a positive or 
negative effect of the soccer tournament. Furthermore, most studies concentrate only on the direct effect of the championship. We also ask and investigate whether hotels and restaurants believe in a positive long-run impact of such events and explore the determinants of these beliefs.

Looking at economic figures during the EURO 2008 soccer championship for Switzerland, we find no effect in the aggregate series. However, consulting a survey of companies conducted during the soccer championship, we can offer a more qualified insight into the economic effects of the event. Surveying hotels and restaurants, we find that firms estimate the EURO to have diminished the year-on-year sales growth by roughly $2.5 \%$ on average. However, the impact is very heterogeneous across companies and sectors. First, hotels in cities report more beneficial sales effects while restaurants in general tend to have experienced worse sales effects. The latter might be partly explained by the additional possibilities to buy drinks outside and the public-viewing spots. Furthermore, the composition of the sales effect is different. While for both restaurants and hotels, the sales effects had a quantity component, there was additionally a price effect for hotels. Apart from the analysis of these short-term effects, we are also able to present information on expected long-run gains. Out of those firms having answered to corresponding question, only $23 \%$ believe in a positive effect. Notably, this response does not depend on the sales impact of the event but on the guest structure. 


\section{References}

Baade, R. and Matheson, V. (2004). The quest for the cup: Assessing the economic impact of the world cup. Regional Studies, 38(4):343-354.

Brenke, K. and Wagner, G. G. (2007). Ökonomische Wirkungen der Fussball-WM 2006 in Deutschland zum Teil überschätzt. DIW Berlin Wochenbericht 29/2007, DIW.

Deutsche Bundesbank (2006). Der WM-Effekt bei den Reiseverkehrseinnahmen in Deutschland. Monatsbericht der deutschen bundesbank november 2006, Deutsche Bundesbank.

Hagn, F. and Maennig, W. (2009). Large sport events and unemployment: the case of the 2006 soccer world cup in germany. Applied Economics, 41(25):3295-3302.

Jasmand, S. and Maennig, W. (2008). Regional income and employment effects of the 1972 munich olympic summer games. Regional Studies, 42(7):991-1002.

Maennig, W. and du Plessis, S. (2007). World cup 2010: South african economic perspectives and policy challenges informed by the experience of germany 2006. Contemporary Economic Policy, 25(4):578-590.

Matheson, V. (2006). Mega-events: The effect of the world's biggest sporting events on local, regional, and national economies. Working Papers 0622, International Association of Sports Economists.

Matheson, V. (2009). Economic multipliers and mega-event analysis. International Journal of Sport Finance, 4(1):63-70.

Rose, A. K. and Spiegel, M. M. (2011). The olympic effect*. The Economic Journal, 121(553):652-677.

Spilling, O. R. (1996). Mega event as strategy for regional development the case of the 1994 lillehammer winter olympics. Entrepreneurship $\&$ Regional Development: An International Journal, 8(4):321-343.

Szymanski, S. (2002). The economic impact of the world cup. World Economics, 3(1):169-177. 
Table 8: Variable Names and Definitions

\begin{tabular}{|c|c|c|}
\hline Variable & Question/Definition & Encoding \\
\hline sales_impact & What impact did the EURO 2008 have on your sales? & $\begin{array}{l}\text {-1: negative impact } \\
0: \text { no impact } \\
\text { 1: positive impact }\end{array}$ \\
\hline impact_surprise & Was the impact (if there was any) as expected? & $\begin{array}{l}-1: \text { worse / less good } \\
0: \text { no impact / as expected } \\
\text { 1: better / less bad }\end{array}$ \\
\hline sales & $\begin{array}{l}\text { What was the percentage change in your sales } \\
\text { in June } 2008 \text {, as compared to June } 2007 ?\end{array}$ & change in $\%$ \\
\hline sales_no_euro & $\begin{array}{l}\text { What percentage change in sales would you have } \\
\text { expected without the EURO } 2008 \text { in June } 2008 \text {, } \\
\text { as compared to June } 2007 ?\end{array}$ & change in $\%$ \\
\hline sales_diff & = sales - sales_no_euro ("EURO premium") & percentage points \\
\hline long_run_eff & $\begin{array}{l}\text { If you experienced positive effects on your sales: } \\
\text { do you expect any positive effects of the } \\
\text { EURO } 2008 \text { on your firm in the long run? }\end{array}$ & $\begin{array}{l}0: \text { no } \\
1: \text { yes }\end{array}$ \\
\hline quantity & $\begin{array}{l}\text { How did the amount of overnight stays / of } \\
\text { food and drinks sold in June } 2008 \text { compare } \\
\text { to June } 2007 \text { ? }\end{array}$ & $\begin{array}{l}-1 \text { : amount decreased } \\
0 \text { : same amount } \\
\text { 1: amount increased }\end{array}$ \\
\hline guest_struct & $\begin{array}{l}\text { Did you receive other guests than } \\
\text { usually in June 2008? }\end{array}$ & $\begin{array}{l}0: \text { no } \\
1: \text { yes }\end{array}$ \\
\hline guest_length & $\begin{array}{l}\text { Did the average length of stay of guests during } \\
\text { the EURO } 2008 \text { differ from the usual length } \\
\text { of stay? (hotels only) }\end{array}$ & $\begin{array}{l}-1 \text { : guests stayed shorter } \\
0 \text { : guests stayed as long as usual } \\
\text { 1: guests stayed longer }\end{array}$ \\
\hline prices & $\begin{array}{l}\text { Did you charge other prices than } \\
\text { usually in June } 2008 ?\end{array}$ & $\begin{array}{l}-1: \text { lower prices } \\
0: \text { same prices } \\
\text { 1: higher prices }\end{array}$ \\
\hline capacity_temp & $\begin{array}{l}\text { Did you increase your capacities temporarily } \\
\text { for the EURO 2008? }\end{array}$ & $\begin{array}{l}0: \text { no } \\
1: \text { yes }\end{array}$ \\
\hline log_empl & Logarithm of number of employees & \\
\hline mountain & Dummy for tourism zone "Mountains" & $0 ; 1$ \\
\hline lake & Dummy for tourism zone "Lakes" & $0 ; 1$ \\
\hline city & Dummy for tourism zone "Big Cities" & $0 ; 1$ \\
\hline hotel & Dummy for hotel sector & $0 ; 1$ \\
\hline hotel_mountain & Dummy for "Hotel in tourism zone mountains" & $0 ; 1$ \\
\hline hotel_lake & Dummy for "Hotel in tourism zone Lakes" & $0 ; 1$ \\
\hline hotel_city & Dummy for "Hotel in tourism zone Big Cities" & $0 ; 1$ \\
\hline hotel_other & Dummy for "Hotel in tourism zone Other Regions" & $0 ; 1$ \\
\hline
\end{tabular}


Table 9: Heckman regression

\begin{tabular}{|c|c|c|}
\hline VARIABLES & sales_diff & selection equation \\
\hline log_empl & & $\begin{array}{c}0.17^{* * *} \\
(0.06)\end{array}$ \\
\hline quantity & $\begin{array}{c}6.49^{* * *} \\
(0.66)\end{array}$ & $\begin{array}{c}0.06 \\
(0.07)\end{array}$ \\
\hline prices & & $\begin{array}{c}-0.02 \\
(0.2)\end{array}$ \\
\hline guest_struc & $\begin{array}{c}3.71^{* * * *} \\
(1.34)\end{array}$ & $\begin{array}{l}0.08 \\
(0.17)\end{array}$ \\
\hline capacity_temp & $\begin{array}{l}3.57^{*} \\
(2.17)\end{array}$ & $\begin{array}{l}0.07 \\
(0.2)\end{array}$ \\
\hline hotel & & $\begin{array}{c}0.43^{* *} \\
(0.17)\end{array}$ \\
\hline city & & $\begin{array}{c}0.1 \\
(0.2)\end{array}$ \\
\hline mountain & & $\begin{array}{c}0.26 \\
(0.19)\end{array}$ \\
\hline lake & & $\begin{array}{c}0.13 \\
(0.18)\end{array}$ \\
\hline hot_city & $\begin{array}{c}5.10^{* * *} \\
(1.89)\end{array}$ & $\begin{array}{c}0.43 \\
(0.39)\end{array}$ \\
\hline Constant & $\begin{array}{c}-4.13^{* * *} \\
(1.05)\end{array}$ & $\begin{array}{c}0.19 \\
(0.18)\end{array}$ \\
\hline athrho & & $\begin{array}{l}-0.01 \\
(0.25)\end{array}$ \\
\hline lnsigma & & $\begin{array}{c}2.37^{* * *} \\
(0.09)\end{array}$ \\
\hline Observations & 573 & 573 \\
\hline
\end{tabular}

